Abstracta Iranica Abstranica

Revue bibliographique pour le domaine irano-aryen

Volume 28 | 2007

Comptes rendus des publications de 2005

\title{
" On Anatolians, Greeks and Egyptians in 'Chaldean' and Achaemenid Babylonia ». Tel Aviv 32/1, pp. 76-106.
}

\section{Astrid Nunn}

\section{OpenEdition}

Journals

Édition électronique

URL : http://journals.openedition.org/abstractairanica/16712

DOI : 10.4000/abstractairanica. 16712

ISSN : 1961-960X

Éditeur :

CNRS (UMR 7528 Mondes iraniens et indiens), Éditions de l'IFRI

Édition imprimée

Date de publication : 15 mai 2007

ISSN : 0240-8910

Référence électronique

Astrid Nunn, « " On Anatolians, Greeks and Egyptians in 'Chaldean' and Achaemenid Babylonia ». Tel Aviv 32/1, pp. 76-106. », Abstracta Iranica [En ligne], Volume 28 | 2007, document 129, mis en ligne le 18 septembre 2007, consulté le 25 septembre 2020. URL : http://journals.openedition.org/ abstractairanica/16712 ; DOI : https://doi.org/10.4000/abstractairanica.16712

Ce document a été généré automatiquement le 25 septembre 2020.

Tous droits réservés 


\title{
«On Anatolians, Greeks and
} Egyptians in 'Chaldean' and Achaemenid Babylonia ». Tel Aviv 32/1, pp. 76-106.

\author{
Astrid Nunn
}

Ran Zadok a déjà livré de nombreux articles sur les populations étrangères en Babylonie achéménide et néo-babylonienne. Ici, il dépouille des textes inédits économiques et de rations qui se trouvent au British Museum et qui datent de 592 à 368 av. J.-C. Les populations concernées sont des Ciliciens, certains peut-être d'origine grecque, des Cariens et des Égyptiens.

\section{INDEX}

Thèmes : 3.2.2. Pré-Achéménides et Achéménides

\section{AUTEURS}

ASTRID NUNN

Université de Munich 